\title{
Cell Hydration Variation is a Primary Mechanism for Itracellular Signaling Sytem
}

\section{Sinerik Ayrapetyan*}

UNESCO Chir - Life Sciences, International Postgraduate Educational Center, 31 Acharyan St., 0040 Yerevan, Armenia

The main omissions from the Classic Membrane Theory (MT) are the explanations of signal transduction in cells by electric conductivity changes of protoplasmic membrane (PM) and considering the cytoplasm (CP) as a simple intracellular electrolytes. This theory did not consider the functional role of water fluxes through the membrane as well as the dynamic changes of cell hydration. It's main statements were developed on the basis of experimental data obtained from the intracellular perfused squid giant axon, in which they continually generate action potentials and functioning of other membrane transporting systems [1]. However, the accumulation of a great number of experimental data on biological effects of extra-weak environmental physical signals [2] and homeopathic concentration of biological active substances [3], which are unable to activate the ionic channels in membrane, on cells and organisms indicate to the incompleteness of this theory.

Parallel to the MT, the so called "Cytoplasm Sorption" theory (ST) was developed, explaining the signal transduction in cell by changes in sorption properties of intracellular macromolecules and organelles [46]. However, ST ignored rather well experimentally documented facts on the functional role of PM in this process, such as in generation of membrane potential, active transport of ions and other metabolites. Because of such non adequate estimation of the functional role of PM, the extremely important statement of this theory on functional role of cell hydration for a long time has been away from adequate attention of researchers. Only during the last 2-3 decades when the "membrane conductive" theory entered its period of crisis, especially explaining the molecular mechanisms of "activation" and "inactivation" of ionic channels as well as in inability to explain the metabolic regulation in conductive function of membrane, the functional role of cell hydration became subject of intensive study [7].

It is known that the PM is more permeable for water. Furthermore, because of the existence of special water channels (aqua pores) in PM, the water transports tough the membrane take place much faster than predicted by simple osmotic diffusion [8]. Therefore, it is obvious that osmotic gradients on membrane generated by extracellular and intracellular factors could have a transient character. Since the valence angle of water molecules, determining its physicochemical properties serves as an extra sensitive and universal sensor for different physical and chemical factors, any factor induced changes thermodynamic activity of membrane bathing aqua mediums could generate water fluxes through the PM. It has been shown that such transient water fluxes through PM have strong modulation effects on membrane conductive function [9] as well as on the water influx - and efflux induced cell hydration and dehydration leading to activation and inactivation of metabolic activity of cell, respectively [10].

It is known that cell hydration regulates the cell metabolic activity by two pathways: a) "folding" of intracellular macromolecules, including DNA [11], and b) surface-dependent regulation of the number of functional active protein molecules (enzymes, receptors, ionic channels) in PM [12-14]. Therefore, the factor induced changes in cell hydration serve as a primary signaling mechanism to switch on cell adaptive metabolic pathways dysfunction of which leads to cell pathology, including aging. By our previous study it was shown that aging-induced depression of $\mathrm{Ca}$ efflux from the heart muscle and brain cells lead to decrease in sensitivity of tissues hydration to different environmental factors because of higher intracellular Ca-induced CP coagulation [15-17]. It was suggested that age-dependent dysfunction of cell hydration controlling mechanisms leading to tissue dehydration serves as a primary messenger for aging-induced increased risk of different medical disorders [16].

Thus, summarizing the presented data, it is suggested that the sensitivity of factor-induced tissue hydration acts as a marker for detection of health status of organism as well as for detection of bioavailability and bioequivalence of drugs.

\section{References}

1. Hodgkin, Alan Lloyd (1964) The conduction of the nervous impulse. Liverpool University Press.

2. Adey WR (1993) Biological effects of electromagnetic fields. J Cell Biochem 51: $410-416$

3. Ayrapetyan SN, Carpenter DO (1991) Very low concentration of acetylcholine and GABA modulate transmitter responses. NeuroReport 2: 563-565.

4. Troshin AS (1966) Problems of cell permeability. Oxford: Pergamon Press.

5. Ling GN (1984) In speech of the physical basis of life. Plenum Publication Co., New York, USA.

6. Pollack GH (2001) Cells, gels and the engines of life. Ebner \& Sons, Seattle WA, USA.

7. Pollack GH, Ivan L, Cameron, Denys N. Wheatley (2006) Water and the Cell. Springer.

8. Huang CG, Lamitina T, Agre P, Strange K (2007) Functional analysis of the aquaporin gene family in C. elegans. Am J Physiol Cell Physiol 292: C18671873.

9. Ayrapetyan SN, Rychkov GY, Suleymanyan MA (1988) Effect of water flow on transmembrane ionic currents in neurons of Helix pomatia and in Squid giant axons. Comp Biochem Physiol A Physiol 89: 179-186.

10. Suleymanyan, MA, Ayrapetyan VE, Arakelian VB, Ayrapetyan SN (1993) The effect of osmotic gradient on the potassium outward current in dialyzed neurons of Helix pomatia. Cell Mol Neurobiol 13: 183-190.

11. Parsegian VA, Rand RP, Rau DC (2000) Osmotic stress, crowding, preferential hydration, and binding: A comparison of perspectives. Proc Nat Sci USA 97 3987-3992.

*Corresponding author: Sinerik Ayrapetyan, UNESCO Chir - Life Sciences, International Postgraduate Educational Center, 31 Acharyan St., 0040 Yerevan, Armenia, E-mail: info@biophys.am

Received July 24, 2013; Accepted July 26, 2013; Published August 02, 2013

Citation: Ayrapetyan S (2013) Cell Hydration Variation is a Primary Mechanism for Itracellular Signaling Sytem. J Bioequiv Availab 5: e35. doi:10.4172/jbb.10000e35

Copyright: $\odot 2013$ Ayrapetyan S. This is an open-access article distributed under the terms of the Creative Commons Attribution License, which permits unrestricted use, distribution, and reproduction in any medium, provided the original author and source are credited. 
Citation: Ayrapetyan S (2013) Cell Hydration Variation is a Primary Mechanism for Itracellular Signaling Sytem. J Bioequiv Availab 5: e35. doi:10.4172/ jbb.10000e35

Page 2 of 2

12. Ayrapetyan SN (1980) On the physiological significance of pump induced cell volume changes. Adv Physiol Sc 23: 67-82.

13. Ayrapetyan SN, Suleymanyan MA, Saghyan AA, Dadalyan SS (1984) Autoregulation of the electrogenic sodium pump. Cell Mol Neurobiol 4: 367383.

14. Parton RG, Simons K (2007) The multiple faces of caveolae. Nat Rev Mol Cell Biol 8: 185-194.

15. Narinyan L, Ayrapetyan G, Ayrapetyan S (2012) Age-dependent magnetosensitivity of heart muscle hydration. Bioelectromagnetics 33: 452458 .

16. Ayrapetyan S (2012) Editorial: The Dysfunction of Metabolic Controlling Cell Hydration is a Primary Mechanism for Generation of Aging - Related Nerve Disorders. J Bioequiv Availab 4:4 ix-xii.

17. Heqimyan A, Narinyan L, Nikoghosyan A, Deghoyan A, Yeganyan L, et al. (2012) Age dependency of high-affinity ouabain receptors and their magnetosensitivity. Environmentalist 32: 228-235. 